This article is from

issue Number 3, 2011, of the

Journal of the

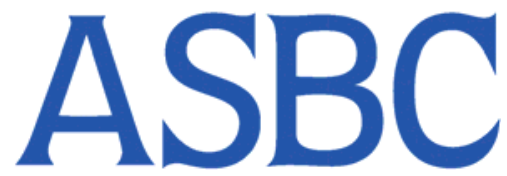

published by the

American Society of Brewing Chemists

For more information on this and other topics

related to the brewing industry,

we invite you to visit ASBCnet at

www.asbenet.org

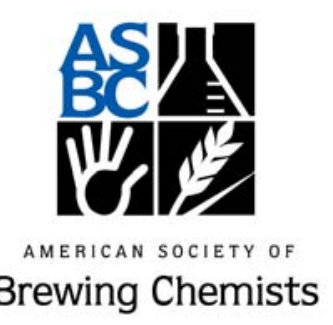




\title{
A High-Maltose Broth Method for Studying the Effects of Amino Acids on Fermentability ${ }^{1}$
}

\author{
Blanca Gómez G., Laboratorio Tecnológico del Uruguay, Montevideo, Uruguay, and Grain Research Laboratory, \\ Canadian Grain Commission, and Food Science Department, University of Manitoba, Winnipeg, MB, Canada; \\ and M. J. Edney, ${ }^{2}$ Grain Research Laboratory, Canadian Grain Commission, and Food Science Department, \\ University of Manitoba, Winnipeg, MB, Canada
}

\section{ABSTRACT}

\section{J. Am. Soc. Brew. Chem. 69(3):127-132, 2011}

Brewery fermentations require sufficient yeast growth during fermentation to achieve the timelines and beer quality expected. It is only possible to obtain the necessary growth when yeast are provided with an adequate supply of all nutrients, including amino acids, minerals, and fermentable sugars. However, a broth made from 100\% high-maltose syrup (HMS), and thus containing no micronutrients, showed excellent fermentability under standard laboratory conditions (Congress wort specific gravity, high pitching rates, and continuous stirring), indicating no requirement for micronutrients under these conditions. The aim of this study was to develop a labscale fermentation test, based on reduced pitching rates and use of adjunct sugars, that would indicate the need for micronutrients during fermentation. Malts from three barley varieties and of varying quality were used to investigate the effectiveness of the test. Amino acid levels in worts and fermented worts were measured using ultra-performance liquid chromatography. Effects of amino acids on fermentability were most apparent when a pitching rate of $0.45 \mathrm{~g}$ of compressed yeast per $100 \mathrm{~mL}$ of broth and a broth with a 40:60 ratio of HMS to Congress wort were used. At least $1,000 \mathrm{mg}$ of amino acids per $\mathrm{L}$ was necessary to completely ferment an $8.5^{\circ} \mathrm{P}$ broth. Individual amino acids were absorbed in the order expected, with the exception of glutamine, a type A amino acid, which was absorbed at a slower rate than the type $\mathrm{B}$ amino acids histidine and methionine. The broth method also found that proline was absorbed even under standard fermentation conditions once other amino acids had been depleted.

Keywords: AAL, Adjunct, Fermentability, Maltose syrup

\section{RESUMEN}

Fermentaciones en la cervecería requiere crecimiento de la levadura durante la fermentación suficiente para alcanzar los plazos y calidad de la cerveza esperada. Sólo es posible obtener el crecimiento necesario cuando la levadura se proporciona con un suministro adecuado de todos los nutrientes, incluyendo aminoácidos, minerales y azúcares fermentables. Sin embargo, un caldo hecho de $100 \%$ de jarabe de alto contenido de maltosa, y por lo tanto no contiene micronutrientes, mostraron una excelente fermentación en condiciones de laboratorio estándar (la gravedad específica del mosto de Congreso, las altas cantidades de levadura a inocular, y agitación continua), indica que no hay necesidad de micronutrientes en estas condiciones. El objetivo de este estudio fue desarrollar una prueba de fermentación a escala de laboratorio, sobre la base de reducidos cantidades de levadura a inocular y la utilización de los azúcares del adjunto, que indican la necesidad de micronutrientes en la fermentación. Maltas de tres variedades de cebada y de calidad variable se utilizaron para investigar la eficacia de la prueba. Los niveles de aminoácidos en mostos y mostos fermentados se midieron utilizando ultra-cromatografía líquida. Efectos de los aminoácidos en la fermentación fueron más evidentes con la cantidad de levadura de inocular de $0.45 \mathrm{~g}$ de levadura pren-

\footnotetext{
${ }^{1}$ Paper 1040 of the Canadian Grain Commission presented at the 14th Australian Barley Technical Symposium, Sunshine Coast, Queensland, Australia, 2009.

${ }^{2}$ Corresponding author. E-mail: michael.edney@ grainscanada.gc.ca; Phone: +1.204. 983.8854; Fax: +1.204.983.0724.
}

doi:10.1094/ASBCJ-2011-0527-02

(C) 2011 Department of Agriculture and Agri-Food, Government of Canada. sada por cada $100 \mathrm{~mL}$ de caldo y un caldo con una relación 40:60 de jarabe de alto contenido de maltosa al mosto de Congreso se utilizaron. Al menos $1,000 \mathrm{mg}$ de aminoácidos por litro era necesario para fermentar completamente un caldo de $8.5^{\circ} \mathrm{P}$. Los aminoácidos individuales fueron absorbidos en el orden esperado, con la excepción de la glutamina, un aminoácido de tipo A, que fue absorbido a un ritmo más lento que el tipo $\mathrm{B}$, aminoácidos histidina y metionina. El método de caldo también encontró que la prolina fue absorbido incluso bajo condiciones normales de fermentación aminoácidos vez otros se habían agotado.

Palabras claves: AAL, Adjuntos cervecero, Fermentabilidad, Jarabe de maltosa

Brewing fermentation is a complex process that converts wort to beer through the metabolic activity of yeast (15). The predominant activity during fermentation is conversion of fermentable sugars to ethanol. Fermentable sugars, therefore, have generally been considered the first limiting factor to fermentation. However, yeast growth, which must occur if fermentability is to be completed within strict timelines (4) and beer quality is to be maintained, requires an adequate supply of all yeast nutrients, not just fermentable sugars. Levels of micronutrients have become a greater concern as breweries shift from traditional all-malt brewing to high-gravity and highadjunct brewing, in which micronutrient levels are often limiting (16). Important nonsugar nutrients include nitrogen, which is provided predominantly by free amino acids; sterols, which are partially supplied by wort lipids but also synthesized by yeast when provided with adequate wort oxygen; and other micronutrients, predominantly minerals supplied by malt and brewing water. Other aspects of malt quality can also restrict fermentation, such as poor malt modification, as indicated by $\beta$-glucan content and Kolbach index $(5,7)$, and the presence of factors responsible for premature yeast flocculation (10). These factors are generally controlled by following standard malt specifications, and nutrient contribution remains the major concern in the brewery.

The supply of assimilable nitrogen, the second most abundant nutrient in wort after fermentable sugars, also has important ramifications for fermentation performance and final beer quality. Nitrogen exhaustion has been proposed as a major factor responsible for the decline in yeast activity noted during the early stages of fermentation (12). Less assimilable nitrogen can lead to sluggish or "stuck" fermentations. The complexity of amino acid uptake and release through yeast metabolism can have important effects on the flavor profile of the final beer (2). The standard method for determining the nitrogen status of a wort involves measuring free amino nitrogen (FAN), a nonspecific measurement that includes all free amino acids (with the exception of proline) and peptides in a wort (11). Yeast, however, assimilates amino acids in an ordered manner during fermentation. As a result, amino acids are not all of equal importance, and they have been grouped into four types based on their order of removal from fermenting wort (8). The effect on fermentation of limiting amounts of individual amino acids is poorly understood, however.

An efficient, reliable lab-scale measurement of fermentability is required to adequately investigate the effects of individual amino acids, as well as other micronutrients, on fermentability. Consis- 
tent, reliable prediction of malt fermentability has always been difficult because fermentation is a biological process that is affected by wort composition and yeast strain and age, as well as by the fermentation conditions (temperature, wort oxygenation, stirring, and length of fermentation). When fermentability is measured in the laboratory, it is generally based on attenuation, the loss of extract due to metabolization of sugars and formation of ethanol by the yeast (3).

Several official methods $(1,6)$ exist for measuring apparent attenuation limit (AAL); all use stirred fermentations to help reduce time requirements. Differences among the methods are related to yeast pitching rate, fermentation temperature, and fermentation time. Comparison of method results are further complicated by use of specific yeast strains by individual breweries and laboratories. It is well known that different yeast strains and ages attenuate wort differently, making comparisons difficult. There has been a movement to adapt the standard lager strain for use in lab-scale fermentation tests (14). Because of the stirring action of lab-scale tests, the tests cannot be used to evaluate the flocculent behavior of yeast, which can be affected by malt and yeast defects (10).

Official lab-based methods rely on rapid fermentability, which requires an excess supply of yeast ( $>100$ million yeast cells $/ \mathrm{mL}$ ) to achieve attenuation in $24 \mathrm{hr}$. However, as a result of excess yeast and the low gravity of Congress worts, yeast growth is not required to complete fermentation in $24 \mathrm{hr}$ (9). Therefore, the effects of an insufficient supply of micronutrients are not demonstrated. In this study, we developed a fermentation test using commercial pitching rates and broths that combine Congress wort and high-maltose syrup (HMS). The method was used to investigate the relationships between micronutrients, amino acids specifically, and fermentability.

\section{EXPERIMENTAL}

\section{Barley and Malt Samples}

Three barley samples were investigated: two Uruguayan varieties, AC Madi and Musa 936, that were grown in northern Uruguay in 2004; and a Canadian variety, AC Metcalfe, that was grown in Saskatchewan, Canada, in 2005. Each 5-kg barley sample was malted in a custom-made, $7-\mathrm{kg}$ pilot plant with independent metal steep tanks, drum germinators, and continuous-rotation drum kilns. The malting schedule used is presented in Table I.

\section{Fermentability Analyses}

Congress worts were prepared from the three malts (AC Madi, Musa 936, and AC Metcalfe) using standard conditions (6). A series of adjunct sugar worts, subsequently referred to as broths, was prepared using a range of HMS/Congress wort ratios. A foundation, high-maltose solution was prepared with a specific gravity similar to Congress wort, approx. $8.5^{\circ} \mathrm{P}$, to eliminate dilution effects during mixing. The $8.5^{\circ} \mathrm{P}$ HMS was prepared by adding $100 \mathrm{~g}$ of brewer's high-maltose corn syrup (CASCO Inc.) to $1 \mathrm{~L}$ of purified water (Millipore Nanopure). The optimum wort/adjunct ratio was investigated by mixing HMS with worts at six different ratios: $100 \% \mathrm{HMS} ; 80 \% \mathrm{HMS} / 20 \%$ wort; $60 \% \mathrm{HMS} / 40 \%$ wort; $40 \% \mathrm{HMS} /$ $60 \%$ wort; $20 \%$ HMS/ $80 \%$ wort; and $100 \%$ wort.

TABLE I

Malting Schedule Used for Three Barley Samples in a 7-kg Malt Plant

\begin{tabular}{ll}
\hline Process & Timelines and Temperatures \\
\hline Steeping & $7 \mathrm{hr}$ wet, $14 \mathrm{hr}$ air, $7 \mathrm{hr}$ wet, and $12 \mathrm{hr}$ air at $13^{\circ} \mathrm{C}$ \\
Germination & $84 \mathrm{hr}$ at $15^{\circ} \mathrm{C}$ \\
Kilning & $12 \mathrm{hr}$ at $55^{\circ} \mathrm{C}, 6 \mathrm{hr}$ at $65^{\circ} \mathrm{C}, 2 \mathrm{hr}$ at $75^{\circ} \mathrm{C}$, and $4 \mathrm{hr}$ at $85^{\circ} \mathrm{C}$ \\
\hline
\end{tabular}

a Steep-out moisture was adjusted to $44 \%$ with addition of up to $300 \mathrm{~g}$ of water at transfer.
The fermentability of Congress wort was measured using standard EBC method 4.11.1 conditions (6). Wort (100 mL) was brought to a boil, cooled to $25^{\circ} \mathrm{C}$, and corrected to volume, and the flask was swirled for $30 \mathrm{sec}$ to achieve aeration. Compressed yeast (AB Mauri Fleischmann's) was used at the specified pitching rate of $7.5 \mathrm{~g}$ in $100 \mathrm{~mL}$ of wort. The yeast type and form were selected for convenience and were different than most brewery yeasts, which could limit the value of some aspects of the research for commercial breweries. Fermentation was carried out at $20^{\circ} \mathrm{C}$ for $24 \mathrm{hr}$ with constant shaking (Innova 40, New Brunswick Scientific). Fermented worts were centrifuged for $5 \mathrm{~min}$ at $10,000 \times g$, followed by filtering through fluted paper $(15 \mathrm{~cm}$, grade $2 \mathrm{~V}$ fluted, Whatman $)$. The density of fermented worts was measured, and percent gravity $\left({ }^{\circ} \mathrm{P}\right)$ loss was reported.

The fermentability of broths was determined using conditions similar to the standard EBC method, with the exception of pitching rate. A series of pitching rates was investigated, including the standard EBC rate (EBC method 4.11.1) of $7.5 \mathrm{~g} / 100 \mathrm{~mL}$ of wort (approx. $1 \times 10^{9}$ cells $/ \mathrm{mL}$ ); the rapid EBC fermentation rate $(\mathrm{EBC}$ method 4.11.2) of $16 \mathrm{~g} / 100 \mathrm{~mL}$ of wort (approx. $2.1 \times 10^{9}$ cells $/ \mathrm{mL}$ ); a level similar to commercial pitching rates at $0.45 \mathrm{~g} / 100 \mathrm{~mL}$ of wort (approx. $6 \times 10^{7}$ cells $/ \mathrm{mL}$ ); and a rate intermediate to the other three rates at $3.0 \mathrm{~g} / 100 \mathrm{~mL}$ of wort (approx. $4 \times 10^{8}$ cells $/ \mathrm{mL}$ ). All fermentations were performed in duplicate, and results were averaged.

\section{Amino Acid Analysis}

An ultra-performance liquid chromatography (UPLC) separation system (ACQUITY UPLC, Waters Corporation) was used to quantify individual free amino acids in fermented and unfermented broths. Samples were filtered using syringe filters (Acrodisc) and 0.2- $\mu \mathrm{m}$ membrane discs (GH Polypro, Pall Corporation) and then diluted 1:10 with water (Nanopure). The amino acid standard solution used to calibrate the equipment was prepared from one ampoule of Waters Amino Acid Hydrolysate Standard, containing a $2.5 \mathrm{mM}$ mixture of 17 hydrolysate amino acids, including ammonia (Waters Corporation), plus cysteine $(1.25 \mathrm{~m} M)$ and $100 \mathrm{~m} M$ solutions of tryptophan, aspartic acid, glutamic acid, and $\gamma$-aminobutyric acid (Sigma-Aldrich). Amino acid totals included 21 amino acids plus ammonia. Standards and samples were derivatized prior to UPLC separation using reagent (AccQ•Fluor, Waters Corporation).

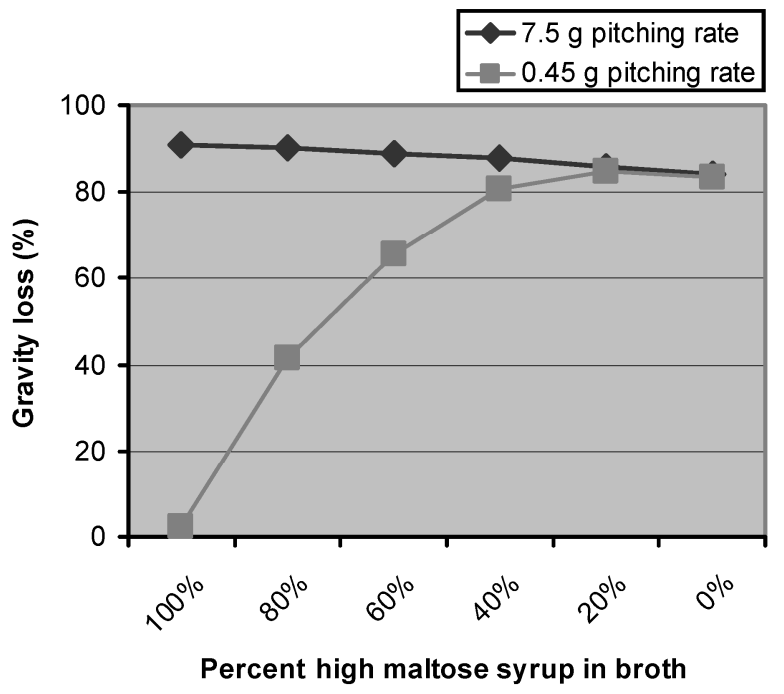

Fig. 1. Effect of pitching rate (g of yeast/100 $\mathrm{mL}$ of broth) on gravity loss after $24 \mathrm{hr}$ of fermentation of broths with varying high-maltose syrup/ Congress wort ratios. 


\section{RESULTS AND DISCUSSION}

\section{Limitations of the Congress AAL Method}

Wort is a complex medium that contains a range of nutrients, predominantly fermentable sugars. Micronutrients, such as amino acids and minerals, are seldom limiting in the all-malt worts normally used for standard analysis of malting quality, which limits their usefulness for research on micronutrient requirements for fermentation. Therefore, to study the effects of amino acid profile on fermentability, broths were developed as controlled model media. HMS and Congress wort were mixed at different ratios to produce broths containing excess levels of fermentable sugars in the presence of limited amounts of free amino acids.

All the broths, despite the proportion of Congress wort, showed excellent fermentability at the standard pitching rate of $7.5 \mathrm{~g}$ of yeast per $100 \mathrm{~mL}$ of broth (Fig. 1). Excellent fermentabilities, as indicated by percent gravity loss, were achieved regardless of nitrogen content. This was best illustrated with the $100 \%$ HMS broth, which contained no added nitrogen but had the greatest loss of gravity $(91.0 \%)$. The medium likely contained sufficient yeast to ferment all the available fermentable sugars without the need for yeast growth (9) and the corresponding need for micronutrients such as nitrogenous compounds. As a result, a range of pitching rates was studied with the aim of restricting the fermentability of broths containing no free amino acids or other micronutrients.

\section{Developing a Fermentability Method Using Broth}

Four pitching rates were assayed: the standard EBC AAL rate $(7.5 \mathrm{~g} / 100 \mathrm{~mL})$; the EBC rapid fermentation rate $(16 \mathrm{~g} / 100 \mathrm{~mL})$; a rate similar to commercial pitching rates $(0.45 \mathrm{~g} / 100 \mathrm{~mL})$; and a rate intermediate to commercial and standard EBC rates $(3.0 \mathrm{~g} / 100 \mathrm{~mL})$. Only the $100 \%$ HMS broth was used to investigate the effect of pitching rate on fermentability. The two highest pitching rates fermented the $100 \%$ HMS broth to near completion, as indicated by gravity losses of nearly $90 \%$ (Table II). The two lower pitching rates were unable to achieve the same result. The lowest rate, the rate similar to commercial rates, showed limited fermentability, with only a $2.5 \%$ loss of gravity in $24 \mathrm{hr}$, which achieved the objective of restricted fermentation for a broth containing no nitrogen.

TABLE II

Effect of Yeast Pitching Rate on Loss of Gravity and Amino Acid Content After $24 \mathrm{hr}$ of Fermentation of $100 \%$ High-Maltose Syrup Broth

\begin{tabular}{lccccr}
\hline & \multirow{2}{*}{$\begin{array}{c}\text { Gravity } \\
\text { Sample }\end{array}$} & \multicolumn{4}{c}{ Amino Acid Content (mg/L) } \\
\cline { 3 - 6 } & Loss $(\%)$ & Histidine & Serine & Lysine & Valine \\
\hline Unfermented broth & $\ldots$ & 0.00 & 20.63 & 0.00 & 0.00 \\
Fermented broth & & & & & \\
0.45 g of yeast & 2.5 & 26.34 & 23.91 & 0.00 & 19.92 \\
3.0 g of yeast & 42.6 & 32.56 & 5.45 & 3.00 & 0.00 \\
7.5 g of yeast ${ }^{\mathrm{a}}$ & 90.3 & 45.40 & 0.00 & 8.97 & 0.00 \\
16.7 g of yeast $^{n}$ & 89.3 & 64.01 & 0.00 & 9.24 & 0.00 \\
\hline
\end{tabular}

${ }^{\mathrm{a}}$ Standard pitching rate used in EBC apparent attenuation limit method (6).
The $0.45 \mathrm{~g} / 100 \mathrm{~mL}$ pitching rate was tested on broths made with varying HMS/wort ratios to prove that increasing free amino acid content, and possibly other micronutrients, would improve fermentability. Gravity loss increased exponentially with an increasing proportion of wort (Fig. 1). The results validated the broth model and supported its use in studying the effects of micronutrients on fermentability. The final broth method was based on $40 \mathrm{~mL}$ of $8.5^{\circ} \mathrm{P}$ HMS mixed with $60 \mathrm{~mL}$ of Congress wort. Broths were fermented with $0.45 \mathrm{~g}$ of compressed fresh yeast per $100 \mathrm{~mL}$ of broth for $24 \mathrm{hr}$ at $20^{\circ} \mathrm{C}$ with constant shaking.

\section{Amino Acid Content}

The amino acid profile of $100 \%$ HMS broth was analyzed before and after fermentation with the tested range of pitching rates (Table II) to determine its nitrogen content. The original 100\% HMS broth unexpectedly contained a significant level of serine $(20.63 \mathrm{mg} / \mathrm{L})$. The fermented $100 \%$ HMS broths contained varying amounts of histidine, serine, lysine, and valine, with no other amino acids detected. At the lowest pitching rate $(0.45 \mathrm{~g} / 100 \mathrm{~mL})$, serine was constant, appearing not to be used, although it may have been cycled by the yeast, while histidine and valine were released into the medium. In contrast, samples fermented at the higher pitching rates ( 7.5 and $16 \mathrm{~g} / 100 \mathrm{~mL}$ ) consumed all of the original serine while releasing higher amounts of histidine, some lysine, and no valine. The broth fermented with the $3.0 \mathrm{~g} / 100 \mathrm{~mL}$ pitching rate produced results intermediate to these observations. Amino acids released during fermentation were likely the result of yeast metabolism, including the pathways of fusel alcohol production and pyruvate and acetylCoA production, both of which would also have contributed to formation of flavor-active metabolites.

Total free amino acid content was analyzed in broths made with different HMS/wort ratios and worts made from the three different malts (Table III). AC Madi broths contained the highest sum of total free amino acid content, which was determined as the sum of all individual amino acid concentrations measured by UPLC, followed closely by AC Metcalfe and then Musa 936 broths. FAN content showed similar trends, with AC Madi and AC Metcalfe broths having levels that were well above those of Musa 936 broths. Total free amino acid content, regardless of the malt, increased with

\section{TABLE IV}

Gravity Loss After $24 \mathrm{hr}$ for Three Malts (Barley Varieties AC Madi, Musa 936, and AC Metcalfe) Determined Using Broths with Varying High-Maltose Syrup/Congress Wort (HMS/W) Ratios ${ }^{\text {a }}$

\begin{tabular}{lccc}
\hline & \multicolumn{3}{c}{ Gravity Loss (\%) } \\
\cline { 2 - 4 } HMS/W Ratio & AC Madi & Musa 936 & AC Metcalfe \\
\hline 80:20 & 38.0 & 35.9 & 43.9 \\
60:40 & 70.5 & 60.2 & 70.2 \\
40:60 & 83.6 & 76.9 & 83.8 \\
20:80 & 83.9 & 81.2 & 85.1 \\
0:100 & 82.0 & 78.6 & 83.3 \\
\hline
\end{tabular}

${ }^{a}$ A pitching rate of $0.45 \mathrm{~g} / 100 \mathrm{~mL}$ of broth was used.

TABLE III

Free Amino Acid and Free Amino Nitrogen (FAN) Contents (mg/L) in Broths Made with Congress Worts from Three Malts (Barley Varieties AC Madi, Musa 936, and AC Metcalfe) and with Broths with Varying High-Maltose Syrup/Congress Wort (HMS/W) Ratios ${ }^{\mathrm{a}}$

\begin{tabular}{|c|c|c|c|c|c|c|}
\hline \multirow[b]{2}{*}{ HMS/W Ratio } & \multicolumn{2}{|c|}{ AC Madi } & \multicolumn{2}{|c|}{ Musa 936} & \multicolumn{2}{|c|}{ AC Metcalfe } \\
\hline & $\begin{array}{c}\text { Sum of } \\
\text { Free Amino Acids }\end{array}$ & $\begin{array}{c}\text { FAN } \\
\text { Calculated }\end{array}$ & $\begin{array}{c}\text { Sum of } \\
\text { Free Amino Acids }\end{array}$ & $\begin{array}{c}\text { FAN } \\
\text { Calculated }\end{array}$ & $\begin{array}{c}\text { Sum of } \\
\text { Free Amino Acids }\end{array}$ & $\begin{array}{c}\text { FAN } \\
\text { Calculated }\end{array}$ \\
\hline $80: 20$ & 480 & 40 & 387 & 32 & 477 & 39 \\
\hline $60: 40$ & 922 & 79 & 717 & 64 & 814 & 77 \\
\hline $40: 60$ & 1,330 & 119 & 969 & 96 & 1,332 & 116 \\
\hline $20: 80$ & 1,917 & 158 & 1,397 & 128 & 1,779 & 154 \\
\hline $0: 100$ & 2,242 & 198 & 1,825 & 160 & 2,064 & 193 \\
\hline
\end{tabular}

${ }^{a}$ FAN content was calculated by dilution of Congress wort values. 
TABLE V

Qualities of Three Malts (Barley Varieties AC Madi, Musa 936, and AC Metcalfe) Used to Verify the Value of Using a Broth Method to Investigate Fermentation

\begin{tabular}{|c|c|c|c|c|c|c|}
\hline Malt & $\begin{array}{c}\text { Fine/Coarse Extract } \\
(\%)\end{array}$ & $\begin{array}{c}\text { Soluble Protein } \\
(\%)\end{array}$ & $\begin{array}{c}\text { Kolbach Index } \\
(\%)\end{array}$ & $\begin{array}{l}\beta \text {-Glucan } \\
(\mathbf{p p m})\end{array}$ & $\begin{array}{c}\text { Diastatic Power } \\
\left({ }^{\circ} \mathbf{L}\right)\end{array}$ & $\underset{(\mathrm{DU})^{\mathrm{a}}}{\alpha \text {-Amylase }}$ \\
\hline AC Madi & 81.4 & 4.80 & 39.6 & 74 & 107 & 60.6 \\
\hline Musa 936 & 79.8 & 4.24 & 38.2 & 213 & 78 & 53.6 \\
\hline AC Metcalfe & 79.9 & 4.76 & 42.3 & 96 & 169 & 82.2 \\
\hline
\end{tabular}

${ }^{\mathrm{a}} \mathrm{DU}=$ dextrinizing units.

TABLE VI

Amounts of Amino Acids Used During $24 \mathrm{hr}$ of Fermentation of Broths with Varying High-Maltose Syrup/Congress Wort (HMS/W) Ratios for Three Barley Varieties (AC Madi, Musa 936, and AC Metcalfe) ${ }^{\mathrm{a}}$

\begin{tabular}{lccc}
\hline \multirow{2}{*}{$\begin{array}{l}\text { HMS/W } \\
\text { Ratio }\end{array}$} & \multicolumn{3}{c}{ Total Free Amino Acids Used (mg/L) } \\
\cline { 2 - 4 } 8C Madi & Musa 936 & AC Metcalfe \\
60:20 & 468 & 374 & 461 \\
$40: 60$ & 915 & 714 & 793 \\
$20: 80$ & 1,322 & 958 & 1,306 \\
$0: 100$ & 1,901 & 1,383 & 1,744 \\
\hline
\end{tabular}

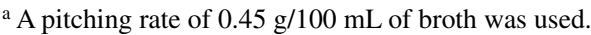

decreasing concentrations of HMS (Table III). Levels of individual amino acids increased in a similar fashion (data not shown).

\section{Use of Amino Acids During Broth Fermentation}

The fermentability of the three malts (AC Madi, Musa 936, and AC Metcalfe) was tested using the low pitching rate and a range of broth ratios (Table IV). The three barley varieties were selected based on their different malting qualities (Table V), particularly their differences in protein modification and the likelihood that their fermentation properties would differ, providing a useful assessment of the broth method. Broths with $80 \%$ wort showed the greatest gravity loss for all three barley varieties. The results were unexpected given higher levels of amino acids and other micronutrients in broths with $100 \%$ wort and the assumption that this would lead to greater gravity loss due to better yeast growth. However, levels of free amino acids and FAN were relatively high in all broths with more than 50\% wort (40:60, 20:80, and 0:100; Table III); therefore, amino acids were likely not limiting in these broths. Fermentable sugars, though, could have been limiting in the $100 \%$ wort broths. The $0: 100$ and 20:80 broths had similar original gravities of $8.5^{\circ} \mathrm{P}$, but their concentrations of fermentable versus nonfermentable sugars differed. The 20:80 broth contained more fermentable sugars because HMS contains predominantly fermentable sugars. The 0:100 broth contained more nonfermentable dextrins from the malt, and therefore, gravity loss was less than for the 20:80 broth. As HMS concentration increased, however, amino acids became limiting (60:40 and 80:20 broths), masking differences in levels of fermentable and nonfermentable sugars.

Levels of FAN and free amino acids declined in all of the 60:40 and 80:20 broths (Table III) to potentially stressful levels (FAN < $80 \mathrm{mg} / \mathrm{L}$ ), and there was a corresponding drop in the fermentability of all broths at these ratios (Table IV). FAN levels were lower than $100 \mathrm{mg} / \mathrm{L}$ in the 40:60 broth of Musa 936, and percent gravity loss was also poor for this broth.

Data on amino acid use during fermentation suggested a minimum requirement for total free amino acid content of $>1,000 \mathrm{mg} / \mathrm{L}$ (Table VI). In the 60:40 and 80:20 broths, where free amino acids were used at $<1,000 \mathrm{mg} / \mathrm{L}$ for all varieties (Table VI), gravity losses were poor, showing losses of $<75 \%$ (Table IV). In the $40: 60$ broths, only Musa 936 used free amino acids at $<1,000 \mathrm{mg} / \mathrm{L}$, and this was the only $40: 60$ broth to have a gravity loss of $<80 \%$.
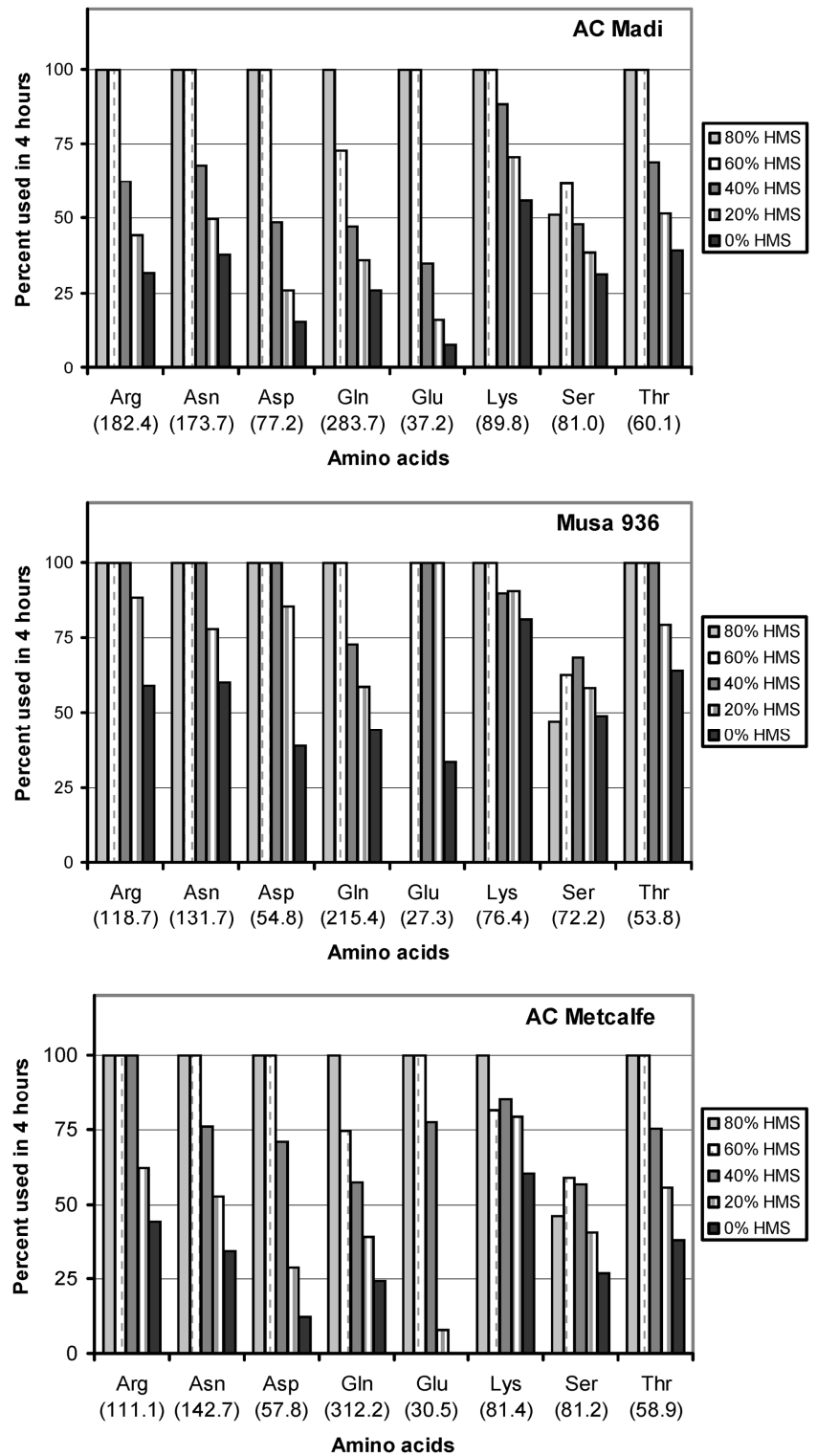

Fig. 2. Percent loss of type A amino acids after $4 \mathrm{hr}$ of fermentation ( $0.45 \mathrm{~g} /$ $100 \mathrm{~mL}$ pitching rate) in broths of three barley varieties (AC Madi, Musa 936, and AC Metcalfe) with varying high-maltose syrup (HMS)/Congress wort ratios. Values on the $\mathrm{x}$-axis indicate initial levels $(\mathrm{mg} / \mathrm{L})$ of individual amino acids in the $100 \%$ wort extract $(0 \%$ HMS $)$. Arg $=$ arginine, Asn $=$ asparagine, Asp = aspartic acid, Gln = glutamine, Glu = glutamic acid, Lys = lysine, $\mathrm{Ser}=$ serine, and Thr $=$ threonine. Note, glutamic acid was not detected in unfermented 80\% HMS broth for Musa 936.

The percent loss of individual amino acids during fermentation varied among amino acids, broth types, and barley varieties. To determine the order of amino acid consumption, levels were monitored at $4 \mathrm{hr}$ of fermentation, because after $24 \mathrm{hr}$ of fermentation 

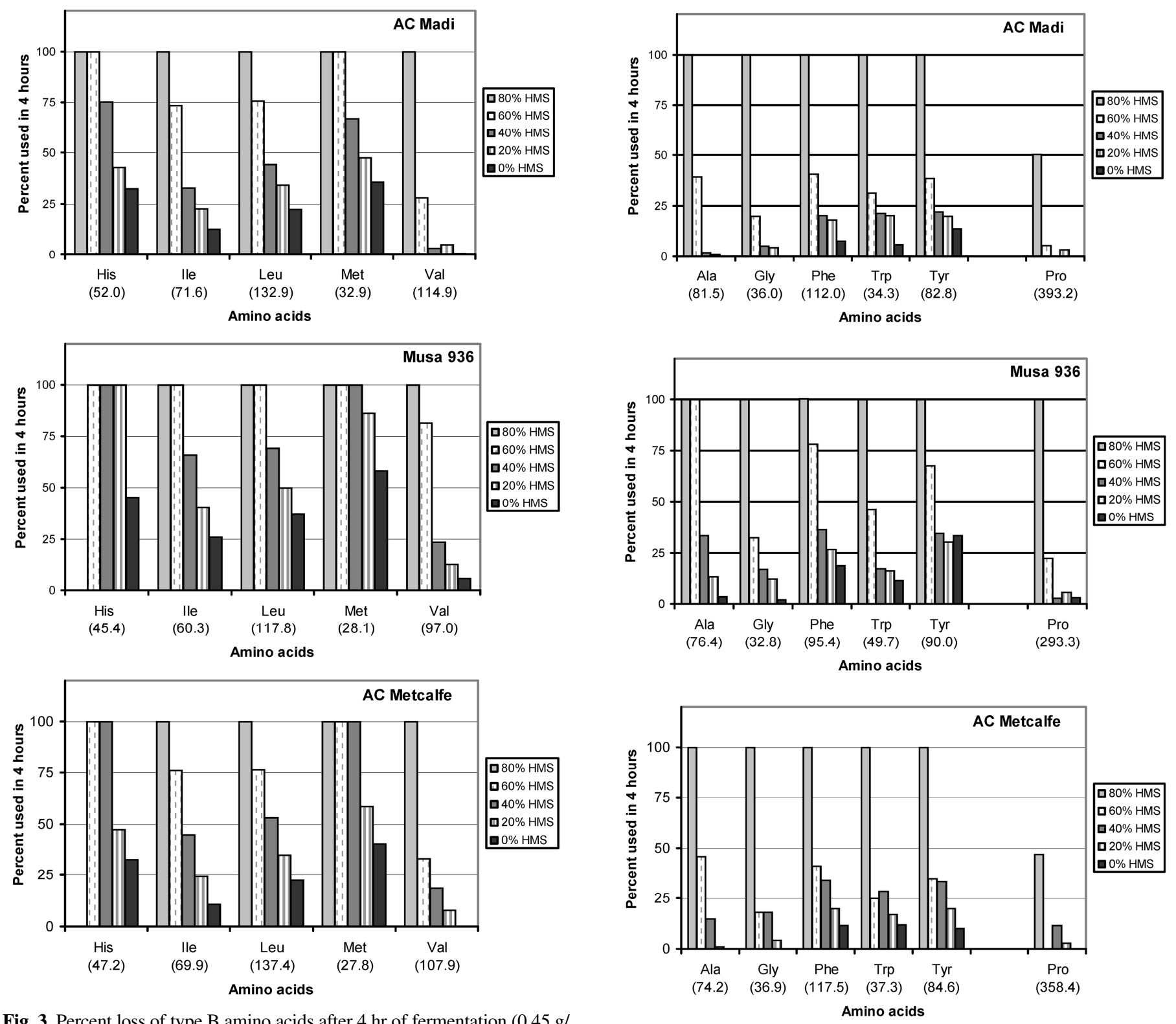

Fig. 3. Percent loss of type B amino acids after $4 \mathrm{hr}$ of fermentation $(0.45 \mathrm{~g} /$ $100 \mathrm{~mL}$ pitching rate) in broths of three barley varieties (AC Madi, Musa 936, and AC Metcalfe) with varying high-maltose syrup (HMS)/Congress wort ratios. Values on the $\mathrm{x}$-axis indicate initial levels $(\mathrm{mg} / \mathrm{L})$ of individual amino acids in the $100 \%$ wort extract $(0 \%$ HMS $)$. His $=$ histidine, Ile $=$ isoleucine, Leu $=$ leucine, Met $=$ methionine, and Val $=$ valine. Note, histidine was not detected in unfermented 80\% HMS broths of Musa 936 or AC Metcalfe.

amino acids were nearly all depleted (data not shown). The type A amino acids arginine, asparagine, aspartic acid, glutamine, glutamic acid, lysine, serine, and threonine were expected to be the first amino acids lost from the wort during fermentation (8). Most type A amino acids were the first to be lost, but there were some exceptions (Fig. 2). Serine loss was limited in all of the broths due to extraordinarily high initial levels brought on by serine contamination of the adjunct syrup (Table II). The contamination could have had consequences for other amino acid losses but was not considered further. Glutamine showed $<80 \%$ loss in 60:40 broths of AC Madi and AC Metcalfe, but the 60:40 broth of Musa 936 showed complete use of glutamine, likely due to lower levels of amino acids in total and, thus, a greater need for glutamine with this variety. Lysine was also not completely used in the 60:40 broth of AC Met-

Fig. 4. Percent loss of type $C$ and $D$ amino acids after $4 \mathrm{hr}$ of fermentation $(0.45 \mathrm{~g} / 100 \mathrm{~mL}$ pitching rate) in broths of three barley varieties (AC Madi, Musa 936, and AC Metcalfe) with varying high-maltose syrup (HMS)/ Congress wort ratios. Values on the $\mathrm{x}$-axis indicate initial levels $(\mathrm{mg} / \mathrm{L})$ of individual amino acids in the $100 \%$ wort extract (0\% HMS). Ala $=$ alanine, Gly = glycine, $\mathrm{Phe}=$ phenylalanine, $\operatorname{Trp}=$ tryptophan, $\mathrm{Tyr}=$ tryrosine, and Pro $=$ proline .

calfe, although it was used completely in the 60:40 broths of the other two varieties. The results suggest that glutamine, and possibly lysine, acted more like a type B amino acid, because some type B amino acids (histidine and methionine) showed greater percent losses than glutamine from 60:40 broths of both AC Madi and AC Metcalfe.

The uptake of the type B amino acids histidine, isoleucine, leucine, methionine, and valine begins as levels of type A amino acids diminish (8). With the exception of histidine and methionine, the type B amino acids behaved as expected (Fig. 3). Histidine and methionine both showed greater use than expected, possibly due to their comparatively low levels in original Congress worts, as listed on the X-axis of Figure 3. Levels of histidine in 80:20 broths of both Musa 936 and AC Metcalfe were below detection 
levels. Histidine and methionine were the only amino acids, other than arginine (type A), that completely disappeared from the 40:60 broth of AC Metcalfe after $4 \mathrm{hr}$ of fermentation. Histidine completely disappeared even from the 20:80 broth of Musa 936, whereas none of the type A amino acids were completely depleted from this broth. The results further emphasize the importance of histidine and the possible need to reclassify it as a type A amino acid.

The type $\mathrm{C}$ amino acids alanine, glycine, phenylalanine, tryptophan, and tyrosine, as well as the only type D amino acid, proline, were expected to be used only after type A amino acids were depleted (8). These amino acids behaved as expected and were only used to a great extent in the 80:20 broth, in which amino acids were most limiting (Fig. 4). The percent use of type $\mathrm{C}$ amino acids decreased to $<20 \%$ as the concentration of Congress wort in broths increased. Significant amounts of proline were used in the 80:20 broths, with complete depletion for Musa 936 and close to $50 \%$ losses for AC Madi and AC Metcalfe. It has often been suggested that proline can only be used in the presence of excess oxygen $(8,13)$; however, the results of this study, in which standard conditions were used for all broths, with no additional oxygen available for the 80:20 broths, suggest that proline was used to meet nitrogenous requirements when all other amino acids were depleted.

\section{CONCLUSIONS}

In conclusion, the pitching rate indicated in standard methods for AAL provided adequate yeast to ferment all the sugars present in Congress wort without the need for yeast growth and without a corresponding requirement for nitrogen or other micronutrients. A pitching rate of $0.45 \mathrm{~g} / 100 \mathrm{~mL}$ of broth was shown to be a good rate for studying the micronutrient requirements of yeast, because broths with as much as $60 \%$ wort had restricted losses of gravity after $24 \mathrm{hr}$, likely due to poor yeast growth brought on by insufficient amino acids and other micronutrients. A supply of at least $1,000 \mathrm{mg}$ of amino acids per $\mathrm{L}$, the sum of individual amino acid contents, was required to complete the fermentation of an $8.5^{\circ} \mathrm{P}$ broth under the test conditions. The amino acids histidine and methionine acted more like type A amino acids than did glutamine. Proline was used to fulfill nitrogenous requirements when all other amino acids were depleted.

\section{ACKNOWLEDGMENTS}

We thank D. Langrell, S. Lowe, A. MacLeod, and S. Parsons for their excellent technical assistance in malting and malt analysis.

\section{LITERATURE CITED}

1. American Society of Brewing Chemists. Methods of Analysis, 9th ed. Beer-2B, Specific gravity by digital density meter; Malt-4 Extract; Wort-5 Yeast fermentable extract, -12 Free amino nitrogen. The Society, St. Paul, MN, 2004.

2. Boulton, C., and Quain, D. Biochemistry of fermentation. In: Brewing Yeast and Fermentation. Blackwell Science Ltd., Oxford. Pp. 69-142, 2001.

3. Briggs, D. E. Malt analyses. In: Malts and Malting. Blackie Academic \& Professional, London. Pp. 579-614, 1998.

4. Casey, G. P., Magnus, C. A., and Ingledew, W. M. High gravity brewing: Nutrient enhanced production of high concentrations of ethanol by brewing yeasts. Biotechnol. Lett. 5:429-434, 1983.

5. Edney, M. J., Eglinton, J. K., Collins, H. M., Barr, A. R., Legge, W. G., and Rossnagel, B. G. Importance of endosperm modification for malt wort fermentability. J. Inst. Brew. 113:228-238, 2007.

6. European Brewery Convention. Analytica-EBC. Malt 4.5.1 Extract of malt: Congress mash; Wort 4.11.1 Fermentability, attenuation limit of wort: Reference method; Wort 4.11.2 Fermentability, attenuation limit of wort rapid fermentation. Fachverlag Hans Carl, Nürnberg, Germany, 1998.

7. Evans, D. E., Li, C., and Eglinton, J. Improved prediction of malt fermentability by measurement of the diastatic power enzymes $\beta$-amylase, $\alpha$-amylase, and limit dextrinase: I. Survey of the levels of diastatic power enzymes in commercial malts. J. Am. Soc. Brew. Chem. 66:223-232, 2008

8. Jones, M., and Pierce, J. S. Absorption of amino acids from wort by yeasts. J. Inst. Brew. 70:307-315, 1964.

9. Kirsop, B. H. Developments in beer fermentation. In: Topics in Enzyme and Fermentation Biotechnology, vol. 6. A. Wiseman, ed. Hatsted Press, Chichester, England. Pp. 79-131, 1982.

10. Lake, J. C., Speers, R. A., Porter, A. V., and Gill, T. A. Miniaturizing the fermentation assay: Effects of fermentor size and fermentation kinetics on detection of premature yeast flocculation. J. Am. Soc. Brew. Chem. 66:94-102, 2008.

11. Lekkas, C., Stewart, G. G., Hill, A. E., Taidi, B., and Hodgson, J. Elucidation of the role of nitrogenous wort components in yeast fermentation. J. Inst. Brew. 113:3-8, 2007.

12. O'Connor-Cox, E. S. C., and Ingledew, W. M. Wort nitrogen sourcesTheir use by brewing yeasts: A review. J. Am. Soc. Brew. Chem. 47: 102-108, 1989.

13. Perpète, P., Santos, G., Bodart, E., and Collin, S. Uptake of amino acids during beer production: The concept of a critical time value. J. Am. Soc. Brew. Chem. 63:23-27, 2005.

14. Speers, A. Miniature fermentation method. J. Am. Soc. Brew. Chem. 68:231-237, 2010.

15. Stewart, G. G., and Russell, I. Fermentation-The "black box" of the brewing process. Tech. Q. Master Brew. Assoc. Am. 30:159-168, 1993.

16. Walker, G. M., De Nicola, R., Anthony, S., and Learmonth, R. Yeastmetal interactions: Impact on brewing and distilling fermentations. In: Proc. 29th Conv. Inst. Brew. (Asia Pac. Sect.), Hobart. IBD, London, 2006. 